\title{
Arahan kebijakan pengendalian dinamika penggunaan lahan pada DAS Antokan, Provinsi Sumatera Barat
}

\section{Policy directions for control of land use dynamics in the Antokan Watershed, West Sumatra Province}

Iswandi Umar

Jurusan Geografi, Fakultas Ilmu Sosial, Universitas Negeri Padang, Prof. Dr. Hamka Air Tawar Padang, 25123, Indonesia [+62 81363315275]

\section{Article Info:}

Received: 26 - 08 - 2020

Accepted: 10 - 02 - 2021

Keywords:

GIS, ISM, land use, policy

direction, watershed

\section{Corresponding Author:}

Iswandi Umar

Jurusan Geografi, Fakultas Ilmu

Sosial, Universitas Negeri

Padang;

Tel. +6281363315275

Email:

iswandi_u@yahoo.com

\begin{abstract}
The need for land has increased every year, and this increase is caused by the rate of population growth, resulting in changes in land use. Uncontrolled land-use conversion has led to catastrophic flooding in the Antokan watershed. The purpose of this study was to determine the direction of land-use change policies in the Antokan Watershed, West Sumatra Province. To determine land-use change using the GIS method with the overlay technique of land use maps for the period 2000-2020. Furthermore, to determine the policy direction using the ISM method involving 20 experts. Research results in the Antokan watershed have shown changes in land use of 4.178 hectares during the 2000-2020 period. Changes occur in forest areas, mixed gardens, shrubs, and rice fields which have decreased, on the other hand, settlements, plantations, and open land have expanded. Furthermore, two sub-elements are the priority for policy direction to reduce the rate of land-use change, namely making regulations and firm sanctions on land use errors (E3) and consistency in enforcing land use laws (E4).
\end{abstract}

How to cite (CSE Style $8^{\text {th }}$ Edition):

Umar I. 2021. Arahan kebijakan untuk mengurangi dinamika penggunaan lahan pada DAS Antokan, Provinsi Sumatera Barat. JPSL 11(1): 10-18. http://dx.doi.org/10.29244/jpsl.11.1.10-18.

\section{PENDAHULUAN}

Pembangunan berkelanjutan pada dasarnya proses pengoptimalan pemanfaatan sumber daya alam untuk kebutuhan generasi sekarang tanpa mengabaikan kebutuhan generasai yang akan datang (WCED, 1987). Pembangunan berkelanjutan memiliki tiga makna yakni: a) pemanfaatan sumber daya alam untuk memenuhi kebutuhan generasi sekarang tanpa mengabaikan kebutuhan generasi di masa yang akan datang; b) pemanfaatan sumber daya alam tidak melebihi daya dukung lingkungan; dan c) mengoptimalkan pemanfaatan sumber daya alam.

Kehidupanan manusia tidak dapat terlepas dari pemanfaatan lahan, sedangkan lahan yang dapat mendukung kehidupan manusia bersifat terbatas (Umar et al., 2017). Keterbatasan lahan yang dapat menopang kehidupan menyebabkan terjadinya konflik dalam pemanfaatannya (Sadyohutomo, 2008). Konflik dalam pemanfaatan lahan, selalu mengalahkan lahan fungsi alami oleh lahan terbangun (Pribadi $e t$ al., 2006; Umar et al., 2018). Dinamika perubahan penggunaan lahan fungsi alami menjadi lahan terbangun akan berdampak menurunkan kualitas lingkungan dan sumber daya alam (Abera et al., 2020). 
Masalah kependudukan merupakan masalah penting di dunia, termasuk Indonesia. Salah satu permasalahan kependudukan itu adalah pertambahan penduduk yang pesat. Pesatnya pertumbuhan penduduk akan mendorong perubahan penggunaan lahan antara lain untuk tempat tinggal dan fasilitas pembangunan. Luas daratan permukaan bumi relatif tetap sedangkan kebutuhan manusia akan ruang tempat tinggal terus meningkat seiring dengan peningkatan jumlah penduduk. Pertambahan jumlah penduduk tersebut secara tidak langsung berdampak terhadap alih fungsi lahan dari lahan alami menjadi lahan terbangun (Pribadi et al., 2006; Fajarini et al., 2015). Selain itu, Rustiadi et al. (2011) menambahkan bahwa perubahan penggunaan lahan sangat dipengaruhi faktor keuntungan ekonomi dari pemanfaatan lahan. Semakin meningkat nilai ekonomi suatu lahan, maka akan mendorong perubahan lahan menjadi lahan terbangun.

DAS Antokan merupakan daerah tangkapan air (catchment area) Pembangkit Listrik Tenaga Air (PLTA) Maninjau. Perubahan penggunaan lahan yang tak terkendali pada DAS Antokan berdampak langsung terhadap debit air Danau Maninjau, dan hal ini berhubungan dengan PLTA Maninjau. PLTA Maninjau merupakan pemasok energi listrik 3 (tiga) provinsi yakni Sumatra Barat, Riau, dan Jambi. Selain itu, dengan perubahan penggunaan lahan DAS Antokan juga berdampak terhadap bencana banjir. Periode 2000-2019, berdasarkan data DBPD Kabupaten Agam telah terjadi peningkatan kejadian bencana banjir sebesar $2.3 \%$ setiap tahun.

Penelitian ini memadukan pendekatan Sistem Informasi Geografi (SIG) dan pendekatan Interpretative Structural Modelling (ISM) dalam menentukan arahan kebijakan untuk mengurangi dinamika perubahan penggunaan lahan pada DAS Antokan. Berdasarkan latar belakang di atas maka penelitian ini bertujuan untuk menentukan dinamika perubahan penggunaan lahan periode 2000-2020 dan menentukan arahan kebijakan untuk mengurangi dinamika perubahan penggunaan lahan pada DAS Antokan.

\section{METODE}

\section{Lokasi dan Waktu Penelitian}

DAS Antokan terdapat pada Kabupaten Agam Provinsi Sumatera Barat, dengan luas sekitar 43000 hektar. Pada DAS Antokan terdapat salah satu danau terbesar di provinsi tersebut yakni Danau Maninjau, dan bermuara ke Samudra Hindia. Secara astronomis DAS Antokan terdapat pada bujur 9948'0"'-100'13'0" BT dan lintang $0^{\circ} 11^{\prime} 0^{\prime \prime}-0^{\circ} 25^{\prime} 0^{\prime \prime}$. Waktu penelitian ini dilaksanakan selama 6 bulan yakni pada periode bulan Januari hingga Juni 2020. Lokasi penelitian disajikan pada Gambar 1.

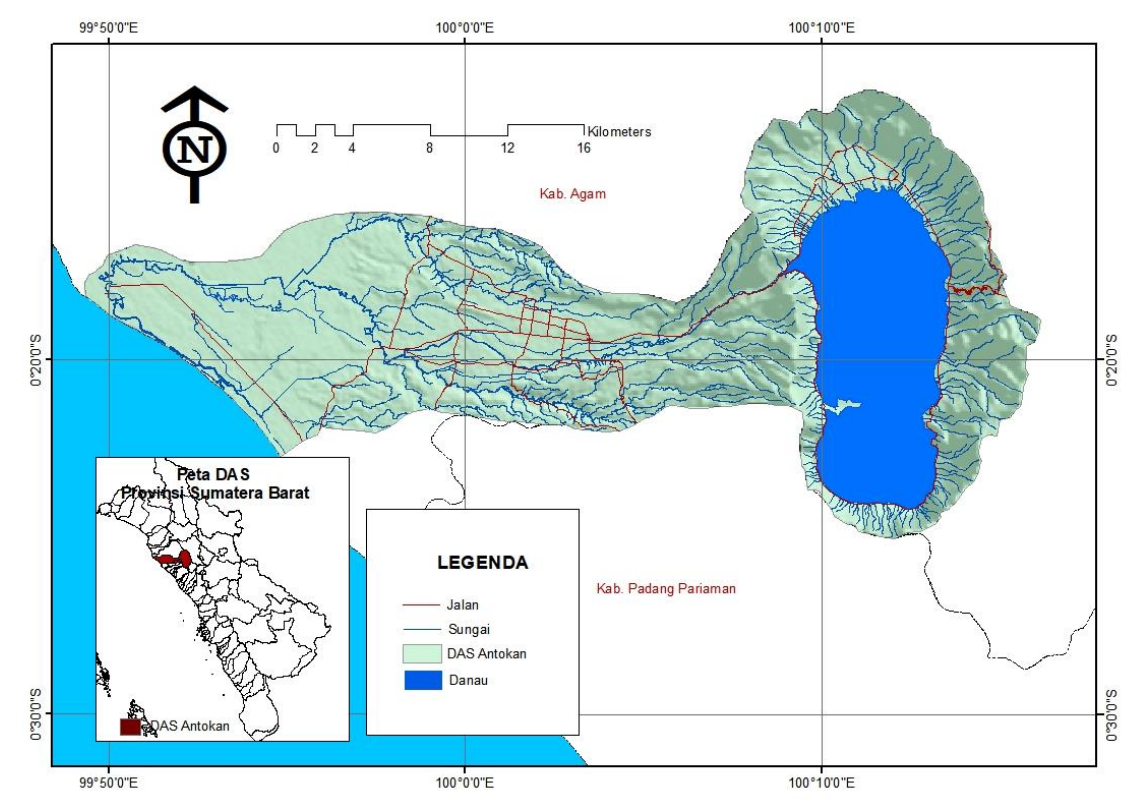

Gambar 1 Lokasi penelitian 


\section{Umar I}

DAS Antokan memiliki topografi dengan ketinggian 0-1.500 meter di atas permukaan laut (dpl). Berdasarkan kemiriangan lereng wilayah ini sebagian besar (55\%) memiliki lereng 17-45\% (agak curamterjal), dan sisanya memiliki kemiringan lereng landai (9-17\%) sebesar $15 \%$ dari luas wilayah dan sekitar $30 \%$ mimiliki kemiringan lereng datar (0-9\%). Penggunaan lahan pada wilayah penelitian berdasarkan interpretasi citra landsat oli 8 tahun 2020 sebagian besar (40.1\%) merupakan merupakan kebun campuran, kawasan hutan (12.3\%), kawasan perkebunan (10.9\%), permukiman (4\%), sawah (26.5\%), semak (2.2\%), dan tanah terbuka $(3.9 \%)$.

\section{Teknik Analisis Data}

Penelitian ini bertujuan untuk menentukan arahan kebijakan untuk perubahan penggunaan lahan pada DAS Antokan. Untuk menentukan perubahan penggunaan lahan, penelitian ini menggunakan metode Sistem Informasi Geografi (SIG) dengan cara analisis overlay peta penggunaan lahan. Perubahan penggunaan lahan yang akan ditentukan dalam penelitian ini yakni periode 2000-2019. Penggunaan lahan pada tahun 2000 dihasilkan dari citra landsat ETM 5. Selanjutnya penggunaan lahan pada tahun 2010 diperoleh dari interpretasi citra landsat ETM 7 tahun 2010, dan penggunaan lahan pada tahun 2019 bersumber dari citra landsat Oli 8 tahun 2020. Untuk menentukan perubahan penggunaan lahan dalam penelitian ini menggunakan software GIS 10.3. Popov et al. (2017) mengemukakan bahwa perubahan penggunaan lahan pada suatu wilayah dapat menggunakan analisis citra dari penginderaan jauh.

Untuk menentukan arahan kebijakan, menggunakan metode Interapretative Structural Modelling (ISM). Metode ISM sangat efektif untuk menstrukturkan masalah yang sangat kompleks, menjelaskan permasalahan, dan menentukan hubungan sebab akibat. Dalam penentuan hubungan kontekstual antar elemen, ditentukan berdasarkan pendapat pakar. Pakar yang terlibat dalam penentuan hubungan kontekstual elemen berasal dari stakeholder yang terkait, yaitu: (1) Pusat Penelitian Kependudukan dan Lingkungan Hidup (PPKLH) UNP; (2) BPBD Kabupaten Agam; (3) Lembaga Swadaya Masyarakat (LSM; (4) Dinas Pekerjaan Umum Kabupaten Agam; dan (5) Tokoh Masyarakat. Jumlah pakar yang terlibat dalam penentuan arahan kebijakan sebanyak 20 orang. Beberapa pertimbangan dalam penentuan pakar dalam penelitian adalah: (1) memiliki pengalaman dengan bidang yang dikaji; (2) mempunyai reputasi atau kompetensi dengan bidang yang dikaji; dan (3) memiliki kredibilitas tinggi terhadap bidang yang dikaji.

Menurut Marimin (2005) secara garis besar terdapat beberapa langkah dalam metode ISM, yaitu: (1) mengurai elemen menjadi beberapa sub elemen; (2) menetapkan hubungan kontekstual antar sub elemen; (3) menentukan Structural Self Intraction Matrix (SSIM); (4) pembuatan Reachability Matrix (RM); (5) melakukan transivity; (6) menentukan struktur hierarki secara vertikal; dan (7) menentukan maktrik hubungan Driver Power (DP) dan Dependence (D). Untuk membuat matriks interaksi SSIM (Structural Self Interaction Matrix), dilakukan dengan cara perbandingan berpasangan dengan simbol VAXO. Dimana simbol tersebut memiliki makna adalah:

a. $\mathrm{V}$ jika Eij= 1 dan $E j i=0 ; \mathrm{V}=$ sub elemen ke i lebih berperan dibandingkan sub elemen ke $\mathrm{j}$ dan tidak sebaliknya

b. $A$ jika $E i j=0$ dan $E j i=1 ; A=$ sub elemen ke $\mathrm{j}$ lebih berperan dibandingkan sub elemen ke i dan tidak sebaliknya

c. $\mathrm{X}$ jika Eij= 1 dan $E \mathrm{ji}=1 ; \mathrm{X}=$ kedua sub elemen mempunyai nilai tingkat peran yang sama dan saling terkait, dan

d. $\mathrm{O}$ jika Eij= 0 dan $\mathrm{Eji}=0 ; \mathrm{O}=$ kedua sub elemen tidak saling terkait.

Selanjutnya Eriyatno (2003) dan Marimin (2005) mengklasifikasikan hubungan elemen menjadi empat kategori yaitu:

a. Kuadran Pertama disebut autonomous, dimana terdiri dari sub elemen yang mempunyai nilai driver power (DP) $\leq 0.5 \mathrm{X}$ dan nilai dependence $(\mathrm{D}) \leq 0.5 \mathrm{X}$. Dimana $\mathrm{X}$ merupakan jumlah sub elemen pada setiap elemen. Sub elemen yang berada pada kuadran pertama ini dapat dimaknai bahwa sub elemen tidak berkaitan/hubungannya kecil dengan sistem. 
b. Kuadran Kedua disebut dependent, terdiri dari sub elemen yang mempunyai nilai driver power (DP) $\leq 0.5 \mathrm{X}$ dan nilai dependence (D) $\geq 0.5 \mathrm{X}$. Sub elemen yang berada pada kuadran kedua ini merupakan sub elemen yang tergantung pada elemen di kuadran ketiga.

c. Kuadran III: Pengait (Linkage) terdiri dari sub elemen yang mempunyai nilai driver power (DP) $\geq 0.5 \mathrm{X}$ dan nilai dependence (D) $\geq 0.5 \mathrm{X}$. Dimana $\mathrm{X}$ adalah jumlah sub elemen pada setiap elemen. Sub elemen yang masuk pada kuadran III ini perlu dikaji secara hati-hati, karena setiap tindakan pada satu sub elemen akan berpengaruh pada sub elemen lain yang berada pada kuadran II dan IV.

d. Kuadran IV: Penggerak (Independent) terdiri dari sub elemen yang mempunyai nilai driver power (DP) $\geq 0.5 \mathrm{X}$ dan nilai dependence $(\mathrm{D}) \leq 0.5 \mathrm{X}$. Dimana $\mathrm{X}$ adalah jumlah sub elemen pada setiap elemen.

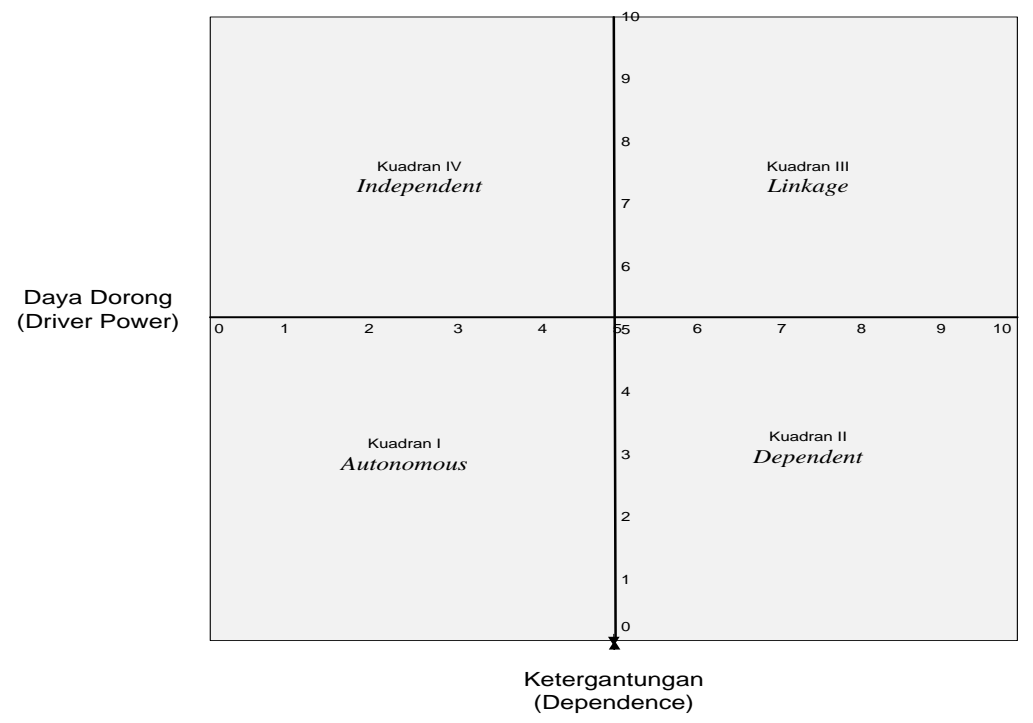

Gambar 2 Matriks driver power dan dependence pada ISM

\section{HASIL DAN PEMBAHASAN}

Pertumbuhan penduduk sangat erat kaitannya dengan dinamika penggunaan lahan, karena dengan peningkatan jumlah penduduk mendorong pertambahan kebutuhan akan lahan baik untuk permukiman maupun untuk lahan pertanian dan industri (Kaur et al., 2004; Liu et al., 2017). Selanjutnya Pribadi et al. (2006) menjelaskan bahwa pembangunan yang pesat akan menyebabkan perubahan pola penggunaan lahan, dimana kawasan terbangun semakin mendominasi dan mendesak lahan bervegetasi untuk berubah fungsi. Tingginya desakan terhadap lahan bervegetasi akan menyebabkan menurunnya kemampuan alami lahan untuk menyerap dan menampung air, terutama pada musim penghujan. Selanjutnya Abera et al. (2020) menambahkan bahwa perubahan penggunaan lahan sebagian besar terjadi pada kawasan hutan lindung, semak, rawa, dan sawah yang berubah menjadi kawasan perkebunan, kebun campuran, permukiman dan industri. Selain itu, Samson et al. (2018) menambahkan bahwa dampak negatif dari alih fungsi lahan dari fungsi ekologis menjadi lahan terbangun menyebabkan kehilangan keanekaragaman hayati. Cilliers (2019) menyatakan bahwa dampak negatif dari perubahan penggunaan lahan tidak hanya kehilangan keanekaragaman hayati, namun perubahan tersebut juga akan menimbulkan bencana alam banjir dan longsor. Oleh karena itu, besarnya dampak buruk perubahan penggunaan lahan untuk keberlanjutan sumber daya alam, sehingga menuntut kehati-hatian dalam pengelolaannya (Chand, 2019).

DAS Antokan merupakan daerah tangkapan Danau Maninjau. Selama periode 2000-2020 telah terjadi alih fungsi lahan dari lahan fungsi alami menjadi lahan terbangun. Luas lahan yang mengalami penambahan terjadi pada penggunaan lahan jenis permukiman dan perkebunan, sedangkan jenis penggunaan lahan yang mengalami pengurangan yakni kawasan hutan, kebun campuran, sawah, semak dan tanah terbuka. Periode 2000-2020 pada wilayah penelitian terjadi penambahan luas lahan permukiman sebesar 1289 hektar dan 


\section{Umar I}

kawasan perkebunan sebanyak 1265 hektar. Sedangkan penggunaan lahan yang mengalami penyusutan terbesar terjadi pada kawasan hutan sebesar 1885 hektar. Gambar 3 disajikan grafik perubahan penggunaan lahan dan Gambar 4 merupakan peta perubahan penggunaan lahan pada DAS Antokan.

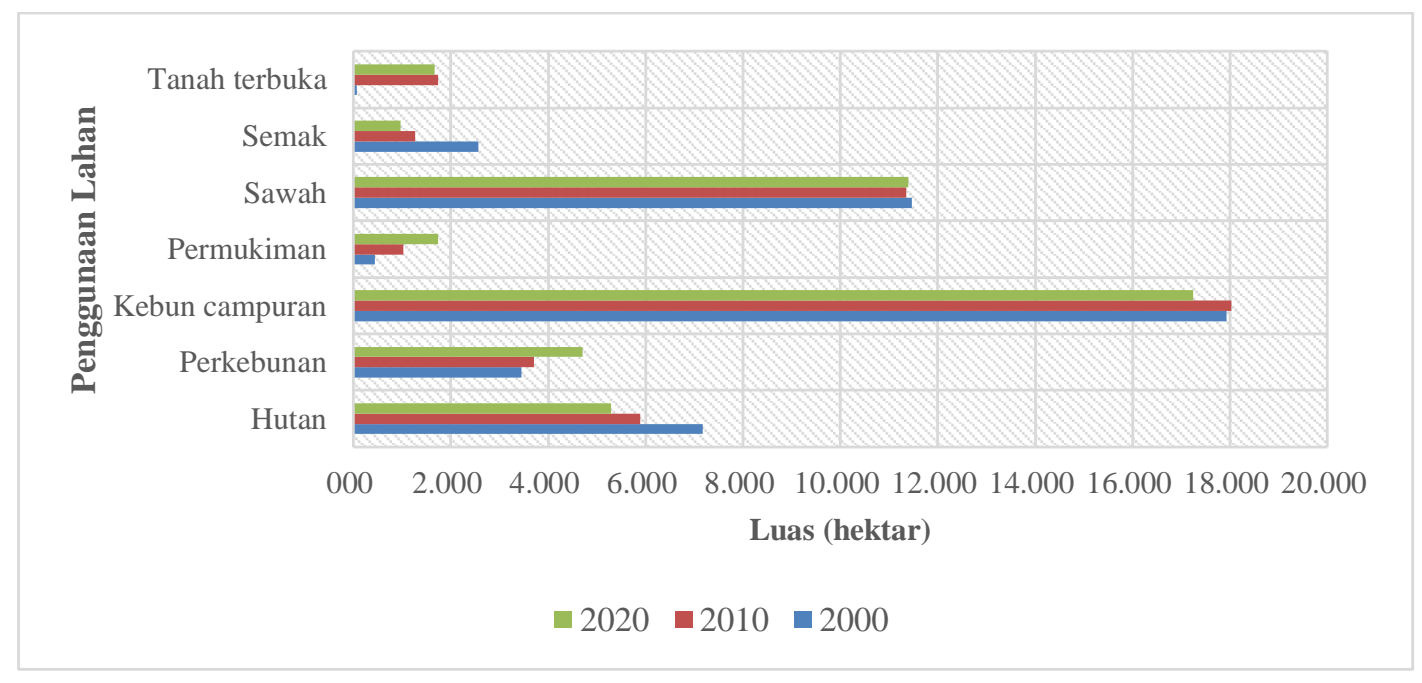

Gambar 3 Grafik dinamika perubahan penggunaan lahan

Dinamika perubahan lahan yang tak terkendali akan mendorong kerusakan lingkungan dan bencana alam pada waktu yang akan datang. Bencana alam dan degradasi lingkungan sebagian besar terjadi karena tidak terkendalikan penggunaan lahan fungsi alami (Umar et al., 2018; Umar et al., 2019b). Oleh karena itu, maka perlu adanya arahan kebijakan untuk mewujudkan pembangunan berkelanjutan. Salah satu metode yang dapat menyelesaikan permasalahan yang memiliki kompleksitas yakni pendekatan Interapretative Structural Modelling (ISM) (Sushil, 2012). Untuk mendapatkan arahan kebijakan dinamika perubahan penggunaan lahan pada DAS Antokan, dilakukan FGD dengan melibatkan pemangku kepentingan (stokeholder). Berdasarkan FGD dengan pakar terdapat delapan sub elemen upaya menekan laju perubahan penggunaan lahan pada DAS Antokan, yaitu: E1= Memperketat pemberian izin pemanfaatan lahan; E2= Kerjasama lintas sektoral dalam pemantauan pemanfaatan lahan oleh masyarakat; E3= Pembuatan regulasi dan sanksi yang tegas dalam kesalahan pemanfaatan lahan; E4= Konsistensi dalam penegakan hukum pemanfaatan lahan; E5= Pembuatan standar teknis pemanfaatan ruang; E6= Sosialisasi tentang lingkungan dan pembangunan berkelanjutan; E7= Keterlibatan tokoh dan atau elemen masyarakat dalam pengawasan lahan; E8= Pembuatan spanduk dan atau himbauan kepedulian lingkungan.

Hasil analisis ISM terhadap arahan kebijakan dinamika perubahan penggunaan lahan pada DAS Antokan berdasarkan penilaian pakar, maka terdapat dua sub elemen yang memiliki driverpower tertinggi yakni sub elemen E2 (pembuatan regulasi dan sanksi yang tegas dalam kesalahan pemanfaatan lahan) dan sub element E4 (konsistensi dalam penegakan hukum pemanfaatan lahan). Selain itu, sub elemen dengan nilai depedence (ketergantungan) yang paling tinggi ialah sub elemen E8 (Pembuatan spanduk dan himbauan kepedulian lingkungan). Gambar 5 merupakan pengelompokan sub elemen pada diagram hubungan antara driverpower dan dependence (ketergantungan). Diagram hubungan tersebut menunjukkan terdapat dua sub elemen (E8 dan E7) kategori dependent, empat sub elemen (E1, E2, E5, E6) kategori lingkage, dan dua sub elemen (E3 dan $\mathrm{E} 4)$ kategori independent. 


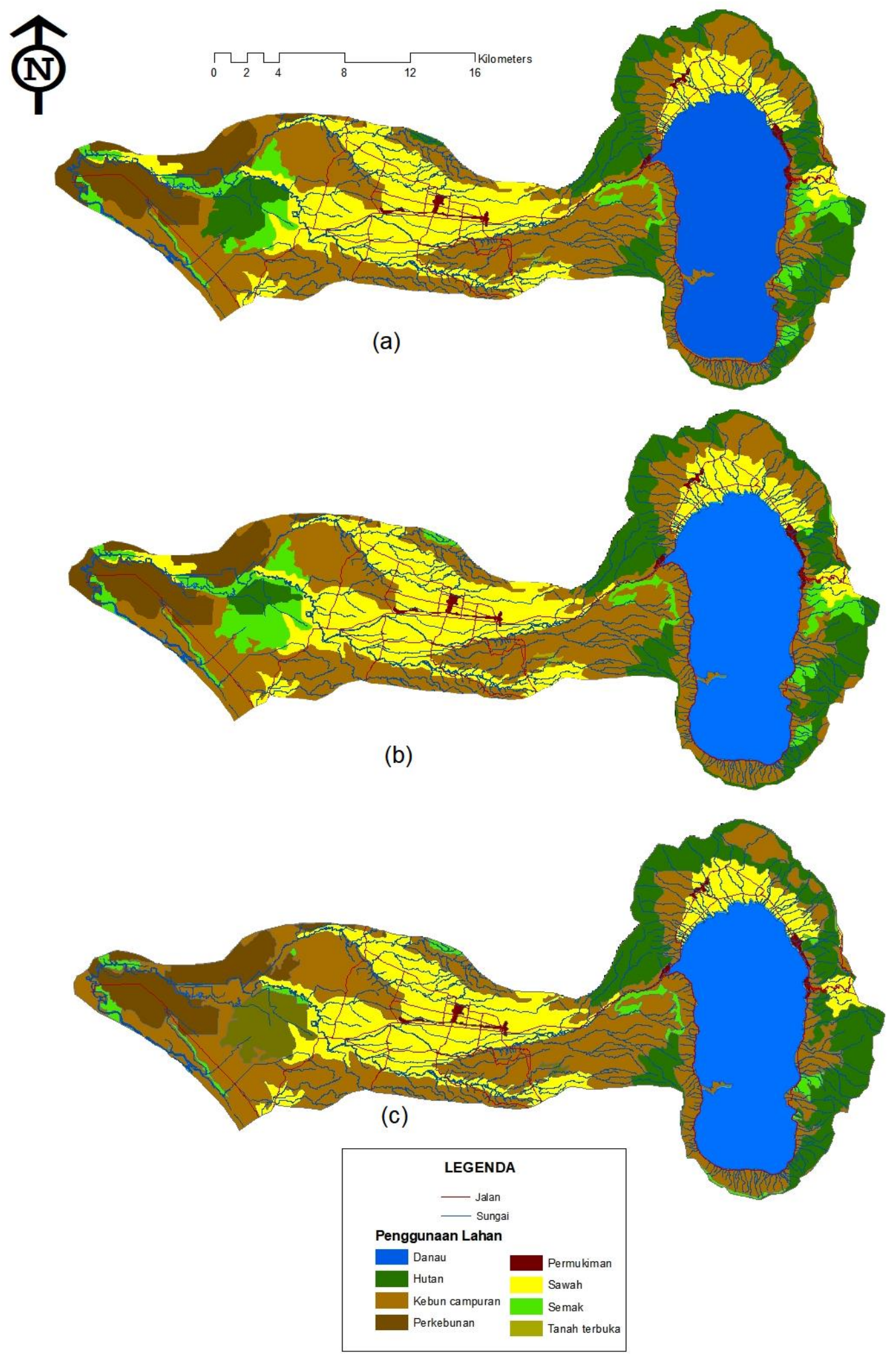

Gambar 4 Peta penggunaan lahan (a) tahun 2000, (b) tahun 2010), dan (c) tahun 2020 


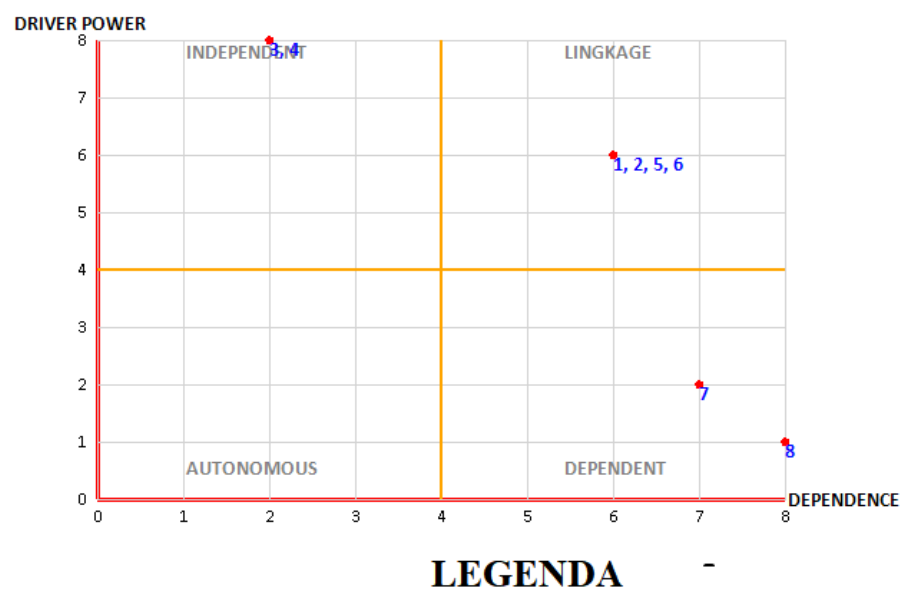

E1. Memperketat pemberian izin pemanfaatan lahan

E2. Kerjasama lintas sektoral dalam pemantauan pemanfaatan lahan oleh masyarakat

E3. Pembuatan regulasi dan sanksi yang tegas dalam kesalahan pemanfaatan lahan

E4. Konsistensi dalam penegakan hukum pemanfaatan lahan

E5. Pembuatan standar teknis pemanfaatan ruang

E6. Sosialisasi tentang lingkungan dan pembangunan berkelanjutan

E7. Keterlibatan tokoh dan atau elemen masyarakat dalam pengawasan lahan

E8. Pembuatan spanduk dan atau himbauan kepedulian lingkungan

Gambar 5 Diagram pengelompokan sub elemen arahan kebijakan dinamika perubahan penggunaan lahan pada DAS Antokan

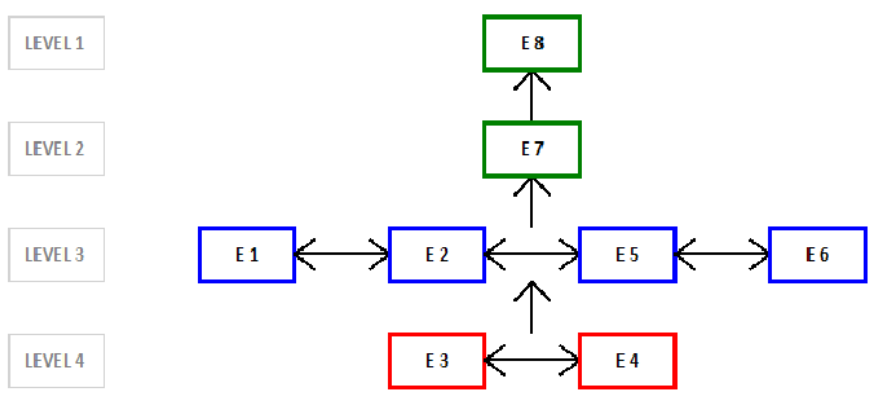

\section{LEGENDA}

E1. Memperketat pemberian izin pemanfaatan lahan

E2. Kerjasama lintas sektoral dalam pemantauan pemanfaatan lahan oleh masyarakat

E3. Pembuatan regulasi dan sanksi yang tegas dalam kesalahan pemanfaatan lahan

E4. Konsistensi dalam penegakan hukum pemanfaatan lahan

E5. Pembuatan standar teknis pemanfaatan ruang

E6. Sosialisasi tentang lingkungan dan pembangunan berkelanjutan

E7. Keterlibatan tokoh dan atau elemen masyarakat dalam pengawasan lahan

E8. Pembuatan spanduk dan atau himbauan kepedulian lingkungan

Gambar 6 Model struktur hierarki sub elemen arahan kebijakan dinamika perubahan penggunaan lahan pada DAS Antokan 
Gambar 6 merupakan model struktur hierarki arahan kebijakan dinamika perubahan penggunan lahan pada DAS Antokan dihasilkan empat level (tingkatan). Pada level 4 terdapat dua sub elemen yang menjadi prioritas kebijakan yakni sub elemen E3 (pembuatan regulasi dan sanksi yang dalam kesalahan pemanfaatan lahan) dan sub elemen E4 (konsistensi dalam penegakan hukum dalam pemanfaatan lahan). Umar et al. (2019a) menyatakan bahwa faktor penyebab terjadinya perubahan penggunaan lahan dibanyak tempat karena lemahnya regulasi dan sanksi yang tegas dari aparat penegak hukum. Selain itu, faktor yang mendorong dinamika penggunaan lahan juga disebabkan oleh lemahnya sinkronisasi dan koordinasi lintas sektoral yang terjadi diberbagai lembaga pemerintahan (Dewata dan Umar, 2019; Umar et al., 2019b).

Umar et al. (2017) menambahkan bahwa kerusakan lahan yang terjadi di banyak tempat di Indonesia disebabkan tidak adanya regulasi yang jelas dan sanksi yang tegas dalam kesalahan pemanfaatan lahan. Akibatnya pelaku perusak lahan dan perambah hutan (deforestasi) menjadi meningkat setiap waktu. Montoya-Zumaeta et al. (2019) menambahkan bahwa peningkatan pelaku perusakan juga didorong oleh faktor ekonomi yang lemah pada masyarakat sekitar hutan. Selain itu, Coals et al. (2019) menjelaskan bahwa lemahnya keterlibatan dan kepedulian masyarakat dalam penjagaan hutan menjadi faktor penambah dalam kerusakan hutan. Oleh karena itu, menurut Urs (2017) ada beberapa upaya untuk menjaga kerusakan hutan antara lain, a) peningkatan peran serta masyarakat sekitar hutan; b) peningkatan pengawasan dan pembuatan regulasi serta sanksi terhadap pelaku kerusakan hutan; dan c) perlu adanya ekonomi alternatif masyarakat sekitar hutan.

\section{SIMPULAN}

DAS Antokan telah terjadi dinamika perubahan penggunaan lahan periode 2000-2020. Hasil analisis periode 2000-2020 pada wilayah penelitian terjadi penambahan luas lahan permukiman sebesar 1289 hektar dan kawasan perkebunan sebanyak 1265 hektar, namun pada penggunaan lahan kawasan hutan, sawah, kebun campuran, semak, dan tanah terbuka mengalami penyusutan. Sebagai arahan kebijakan untuk mengurangi terjadinya dinamika perubahan penggunaan lahan pada DAS Antokan berdasarkan analisis ISM dengan melibatkan stakeholder menghasilkan nilai driverpower tertinggi pada sub elemen E3 (pembuatan regulasi dan sanksi yang dalam kesalahan pemanfaatan lahan) dan sub elemen E4 (konsistensi dalam penegakan hukum dalam pemanfaatan lahan), namun sub elemen dengan nilai depedence (ketergantungan) yang paling tinggi ialah sub elemen E8 (pembuatan spanduk dan himbauan kepedulian lingkungan). Selain itu, model struktur hierarki yang menjadi arahan kebijakan dinamika perubahan penggunan lahan pada DAS Antokan dihasilkan empat level (tingkatan). Pada level 4 terdapat dua sub elemen yang menjadi prioritas kebijakan yakni sub elemen pembuatan regulasi dan sanksi yang dalam kesalahan pemanfaatan lahan (E3) dan sub elemen konsistensi dalam penegakan hukum dalam pemanfaatan lahan (E4).

\section{DAFTAR PUSTAKA}

[WCED] World Commission on Environment and Development. 1987. Our Common Future. United Nation World Commission on Environment and Development. London (GB): Oxford University Pr.

Abera A, Yirgu T, Uncha A. 2020. Impact of resettlement scheme on vegetation cover and its implications on conservation in Chewaka District of Ethiopia. Environmental Systems Research. 9: 1-17.

Chand BJK. 2019. land management problems in Nepal: repercussions of land use policy and implementation gaps in regional and urban planning. ISPRS Annals of the Photogrammetry, Remote Sensing and Spatial Information Sciences. 4: 17-24.

Cilliers DP. 2019. Considering flood risk in spatial development planning: A land use conflict analysis approach. Jàmbá. 11(1): 1-9.

Coals P, Burnham D, Johnson PJ, Loveridge A, Macdonald DW, Williams VL, Vucetich JA. 2019. Deep uncertainty, public reason, the conservation of biodiversity and the regulation of markets for lion skeletons. Sustainability. 11: 1-15. 
Dewata I, Umar I. 2019. Management of flood hazard areas in Pasaman River Basin of West Pasaman Regency West Sumatra Province. Internatio International Journal of GEOMATE. 17: 230-237.

Eriyatno. 2003. Ilmu Sistem Meningkatkan Mutu dan Efektivitas Manajemen. Jilid Satu. Bogor (ID): IPB Press.

Fajarini R, Barus B, Panuju DR. 2015. Dinamika Perubahan penggunaan lahan dan prediksinya untuk tahun 2025 serta keterkaitannya dengan rencana tata ruang 2005-2025 di Kabupaten Bogor. Jurnal Tanah Lingkungan. 17(1): 8-15.

Kaur E, Palang H, Soovali H. 2004. Landscapes in change-opposing attitudes in Saaremaa, Estonia. Landscape and Urban Planning, 67: 109-120.

Liu X, Liu H, Chen W, Zhang Z. 2017. Spatiotemporal fragmentation of urban residential land use: A case study from China. Sustainability. 9: 1-13.

Marimin. 2005. Teknik dan Aplikasi Pengambilan Keputusan Kriteria Majemuk. Bogor (ID): IPB Press.

Montoya-Zumaeta J, Rojas E, Wunder S. 2019. Adding rewards to regulation: The impacts of watershed conservation on land cover and household wellbeing in Moyobamba, Peru. PLoS One. 14(11): 1-22.

Popov M, Fedorovsky O, Stankevich S, Filipovich V, Khyzhniak A, Piestova I, Svideniuk M. 2017. Remote sensing technologies and geospatial modelling hierarchy for smart city support. ISPRS Annals of the Photogrammetry, Remote Sensing and Spatial Information Sciences. 4: 51-56.

Pribadi DO, Shiddiq D, Ermyanyla M. 2006. Model perubahan tutupan lahan dan faktor-faktor yang mempengaruhinnya. Jurnal Teknologi Lingkungan. 7: 35-51.

Rustiadi E, Saefulhakim S, Panuju DR. 2001. Perencanaan dan Pengembangan Wilayah Jakarta. Jakarta (ID): Crespent Press dan Yayasan Obor Indonesia.

Sadyohutomo M. 2008. Manajemen Kota dan Wilayah Realitas dan Tantangan. Jakarta (ID): Bumi Aksara Pr.

Samson EA, Boykin KG, Kepner WG, Andersen MC, Fernald A. 2018. Evaluating biodiversity metric response to forecasted land use change in The Northern Rio Grande Basin. Environments. 5: 1-17.

Sushil. 2012. Interpreting the interpretive structural model. Global Journal of Flexibel Systems Management. 13(2): 87-106.

Umar I, Widiatmaka, Pramudya B, Barus B. 2017. Evaluasi Kesesuaian Lahan untuk Permukiman dengan Pendekatan MCE di Kota Padang. JPSL. 2(2): 84-95.

Umar I, Dewata I, Barlian E, Hermon D, Suasti Y. 2018. Priority selection of residential development areas with flood hazard in Limapuluh Kota District, West Sumatra. International Journal of GEOMATE. 15(52): 152-158.

Umar I, Dewata I, Barlian E. 2019a. Dynamic model of land use change in landslide hazard zones in Tanah Datar District, West Sumatra. IOP Conference Series: Earth and Environmental Science. 314: 1-9

Umar I, Dewata I, Barlian E. 2019b. Konsistensi rencana tata ruang permukiman dan arahan kebijakan pembangunan di Kabupaten Tanah Datar, Provinsi Sumatera Barat. Journal of Natural Resources and Environmental Management. 9(2): 277-286.

Urs SB. 2017. Regulation as a policy contest: The probability of conservation of a renewable resource. Environmental Economics. 8(3): 92-101. 